\title{
Toll-like receptors in domestic animals
}

\author{
Thomas W. Jungi • Katja Farhat • Iwan A. Burgener • \\ Dirk Werling
}

Received: 8 June 2010 /Accepted: 1 September 2010 /Published online: 7 October 2010

(C) Springer-Verlag 2010

\begin{abstract}
Toll-like receptors are pattern recognition receptors with which hosts recognize pathogen-associated molecular patterns (PAMP). This recognition process is translated rapidly into a meaningful defense reaction. This form of innate host defense is preserved in the animal kingdom: invertebrates heavily depend on it; higher vertebrates also have an adaptive immune system. Both adaptive and innate immune systems are intertwined in that the former also depends on an intact innate recognition and response system. Members of the TLR system cover recognition of parasitic, bacterial or viral germs. Due to the constraints imposed by the necessity to recognize PAMP and to interact with downstream signaling mole-
\end{abstract}

\section{T. W. Jungi $(\bowtie)$}

Institute of Veterinary Virology,

Vetsuisse Faculty, University of Bern,

Laenggasstrasse 122,

CH-3001 Bern, Switzerland

e-mail: thomas.jungi@ivv.unibe.ch

\section{A. Burgener}

Division of Small Animal Internal Medicine,

Vetsuisse Faculty, University of Bern,

Bern, Switzerland

K. Farhat

Borstel Research Center,

Borstel, Germany

\section{Werling}

Royal Veterinary College,

Department of Pathology and Infectious Diseases,

Hawkshead Lane,

Hatfield AL9 7TA, UK

Present Address:

K. Farhat

Institute of Physiology, University of Goettingen,

Goettingen, Germany cules, the TLR system is relatively conserved in evolution. Nevertheless, subtle species differences have been reported for several mammalian TLR members. Examples of this will be given. In all mammalian species investigated, part of the coding sequence is available for the most important TLR members, thus allowing study of expression of these TLR members in various tissues by reverse-transcription polymerase chain reaction in its classical (RT-PCR) and quantitative real time RT-PCR (qRT-PCR) form. In some species, the whole coding sequences of the most important or even all TLR members are known. This allows construction of cDNA and transfection of common host cells, thus permitting functional studies. Extensive investigations were devoted to the study of non-synonymous single nucleotide polymorphisms. In a few cases, expression of a given amino acid in the extracellular (ligandbinding) portion of TLR members could be associated with infectious diseases. This will be discussed below.

Keywords Toll-like receptors $\cdot$ Pattern recognition receptors · PRR · TLR · Pathogen-associated molecular patterns

\section{Introduction}

Toll-like receptors (TLR) are a family of germ-line-encoded receptors of the innate immune system. Collectively, they cover the recognition of a wide variety of pathogens (viruses, bacteria, blood-borne parasites), thereby inducing a fast and appropriate host defense reaction against these. Being conserved in evolution, they represent the prime host defense mechanism of invertebrates and lower vertebrates. In higher vertebrates (from gnathostomes up), they are not only essential for sensing microbes by the innate immune 
system but also for inducing a clonally restricted, antigenspecific response in the adaptive immune system, mediated by B and T cells (Medzhitov et al. 1997). This chapter briefly reviews how interest arose in TLR members, then lists some burning questions in different species, summarizes the approaches that have to be taken when studying the TLR system in domestic animals, and finally goes more specifically into what is known in species of domestic animals.

\section{Early investigations in invertebrates}

The term "toll-like receptors" suggests that there is also a "toll". Indeed, when a doctoral student in the laboratory of Nuesslein-Volhard found that, in a Drosophila mutant in which a gene was lacking, the dorsoventral orientation of larvae was ablated, she expressed, in her German, "toll" (great), and thus a gene important for the larval development of Drosophila melanogaster was named (Anderson et al. 1985). The ligand of that receptor was not a pathogen, but a cleaved fly glycoprotein with the name of "spaetzle" (Morisato and Anderson 1994). Later on, it was realized that the cell-membrane-expressed receptor "Toll" also has an important function in adult flies by mediating the recognition of fungi and inducing a meaningful host response against these (Lemaitre et al. 1996). This fundamental observation was the reason for also looking for "Toll" in higher vertebrates (see below).

\section{Early investigations in vertebrates}

There are two early traces of linking mammals to TLR: (1) the seminal discovery that TLR4 is the signaling part of the lipopolysaccharide (LPS) receptor (Poltorak et al. 1998) alluded to in more detail by Van der Pool (2010, this issue), and (2) the observation that innate immune recognition by the TLR is essential for the mounting of an adaptive immune response (Medzhitov and Janeway 1997). After these pivotal observations, the area virtually exploded, and rapid progress was made particularly with regard to innate recognition of pathogens and their products. Fascinatingly, Toll homologues or TLR are highly conserved between invertebrates and vertebrates. A great number of different TLR have been identified, and the number of expressed receptors varies between species from 1 in the nematode Caenorabditis elegans (Kanzok et al. 2004) to 222 in the sea urchin Strongylocentrotus purpuratus (Roach et al. 2005). In higher vertebrate species, 13 TLR members have been identified, subsumed in the following as the TLR system. For 10 of them, natural ligands of pathogens are known. Subsequently, discoveries were made rapidly in mice and humans, particularly with regard to the binding specificity of members of the TLR family, and to the signaling chains involved. To knockout genes involved either in the sensing of pathogens or in signaling and mediating a defense reaction was central. There are a number of excellent reviews of these findings (Akira et al. 2001; Kaisho and Akira 2006; Beutler et al. 2006; Werling and Coffey 2007); one might also study this special issue. However, the expression and function of TLR by domestic animals lagged behind. This area has been comprehensively reviewed by Turin and Riva (2008). While there are a total of 13 TLR members described in mammals, there are 10 genes in most mammals, 10 genes in the chicken, 3 of which are unique to birds (Temperley et al. 2008), and approximately 17 genes in all bony fishes investigated so far (Rebl et al. 2010).

\section{Receptors for pathogen- or microbe-associated molecular patterns?}

Those who coined the expression "pathogen-associated molecular patterns (PAMP)" meant that protection against certain pathogenic microbes is achieved by innate recognition and an appropriate defensive response against these microbes. Put another way, their wording suggests that it is the immune system that discriminates between benign microbes and harmful pathogens compromising the health of the host. That this concept cannot be maintained, in the case of the TLR system, was realized soon thereafter, and the term "microbe-associated molecular pattern (MAMP)" was coined (Mackey and McFall 2006). In the case of a viral infection, one could argue that any intrusion of a virus into host cells in vivo is inappropriate regardless of the pathogenicity of the virus, and therefore any virus has to be regarded as pathogenic. Thus, in the case of a viral infection, the terms PAMP and MAMP have the same meaning. But what discriminates a harmless bacterial intruder from a truly pathogenic bacterium? Both are recognized by the TLR system. That there is a difference between PAMP and MAMP becomes immediately obvious in the case of the gastrointestinal tract harboring myriads of benign bacteria but depending - so it is believed - on the TLR system to cope with a potentially harmful pathogen. Rakoff-Nahoum et al. (2004) even reported that stimulation of the TLR system is absolutely required for a normal development of the gastrointestinal tract. There is no doubt that non-pathogenic bacteria also trigger the TLR system, which consequently fails to discriminate between benign and pathogenic bacteria. What exactly characterizes pathogenic bacteria or blood parasites and distinguishes them from harmless counterparts is unknown. It has been suggested that it is the strategic positioning that allows 
discrimination (Gewirtz et al. 2001). Accordingly, benign bacteria are localized only in the colon lumen, where they are disregarded by the TLR system. In contrast, the flagellin of pathogenic Salmonellae gets access to the basolateral side of the epithelium where it is sensed by basolaterally expressed TLR5. (This, however, does not explain why in fishes there is a soluble variant of TLR5, TLR5S; see below.) The finding of Burgener et al. (2008), that dysregulated TLR expression of dogs with inflammatory bowel disease is not normalized after these dogs are treated and get clinically better, is illustrative in this context. It suggests that a healthy, not dysregulated, TLR system in the gastrointestinal tract is finely balanced in order to protect a host from infection on one hand and to avoid inflammatory sequelae triggered by the immune system in its fight against the intruder on the other hand. Be this as it may, the very properties of PAMP sensed by pattern recognition receptors (PRR) are incompatible with a discrimination between benign and pathogenic bacteria. For investigators of the gastrointestinal tract and its immunology, it is advised to give priority to the term MAMP over PAMP.

\section{Binding specificity of mammalian TLR members}

It is agreed that three preconditions are required for a PAMP to qualify as such and to be recognized by PRR such as TLR: (1) its broad expression by large groups of potential pathogens; (2) its essentiality for survival and successful propagation of the pathogen in question; and (3) its absence from tissues of the host species. The TLR system of higher vertebrates, which is discussed here, perfectly qualifies as a pattern recognition system that covers sensing of the full spectrum of microbes. (Although more PAMP were reported to be recognized by the TLR system, some of which are probably endogenous, and only the most important ones are summarized here, and a discussion as to whether other potential TLR agonists exist is avoided.) TLR4 is the first identified and probably beststudied TLR. In cooperation with three other proteins, the lipopolysaccharide binding protein (LBP), CD14 and MD2 , it is responsible for the sensing of lipopolysaccharide (LPS), the so-called endotoxin of gram-negative bacteria (Poltorak et al. 1998; Medzhitov et al. 1998; Sauter et al. 2007). The heterodimer formed between TLR 2 and TLR6 or TLR1 is able to recognise diacylated or triacylated lipopeptides (LP) found on the surface of all bacteria, respectively (Takeda et al. 2003; Kawai and Akira 2006). TLR5 recognizes flagellin of bacteria (Hayashi et al. 2001). TLR9 binds motifs of CpG DNA, i.e. stretches that are frequently found in microbial DNA whereas they are rare in higher vertebrates, and if expressed, they are methylated and are therefore inaccessible for TLR9 recognition (Hemmi et al. 2000). TLR3 recognizes double-stranded RNA (Alexopoulou et al. 2001). TLR7 and 8 recognize imidazoquinolines used as antiviral compounds (e.g., imiquimod and resiquimod). Later, it was first realized by Heil et al. (2004) that TLR7 and 8 recognize singlestranded RNA, as often occurring in viruses. TLR3, 7, 8 and 9 are expressed in endosomal vesicles (Fig. 1), thereby being separated from host nucleic acids. TLR11, present only in the murine system, senses uropathogenic bacteria, although the exact PAMP, at the molecular level, is unknown. Ligands for TLR10 and members with numbers $>11$ are not yet known in mammals, but have been identified in chicken and fish, potentially representing the homologues of mammalian TLR.

In the literature, one finds the statement that TLR2 heterodimers recognize lipoteichoic acid (LTA) and peptidoglycan (PG) (Schwandner et al. 1999). The TLR
Fig. 1 Illustration of localization of various mammalian TLR in cells. TLR consist either of extracellular or intraluminal LRR recognizing the PAMP (upright green ellipses), of a short transmembrane region (not shown) and of cytoplasmatic TIR domains (green circles). Endosomal vesicles: white circles. Cell nucleus: dark gray circle

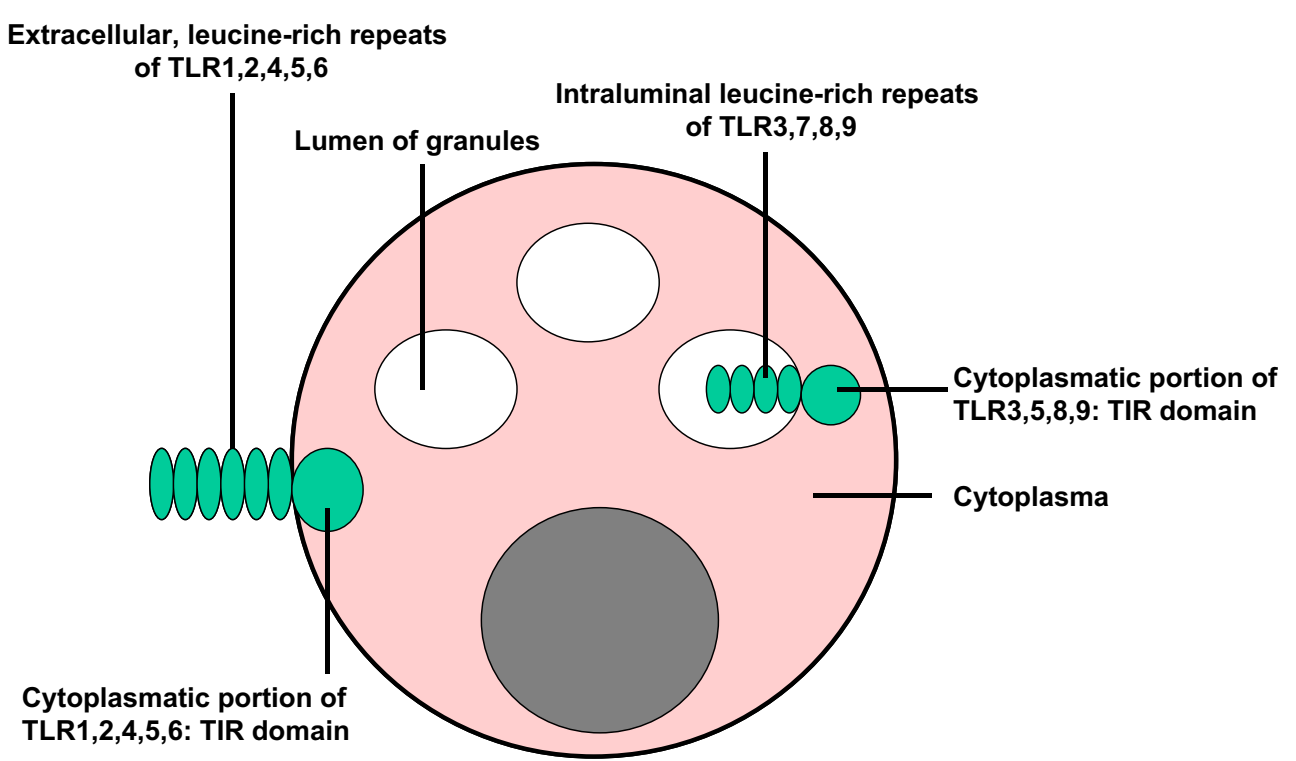


requirement for LTA recognition is controversial (Schwandner et al. 1999; Takeuchi et al. 1999). LTA preparations are notoriously contaminated by lipopeptides (LP); and there is evidence that the active components of LTA are contaminating LP (Hashimoto et al. 2006). Likewise, there is published evidence that $\mathrm{PG}$ are recognized by NOD1/NOD2, but not by TLR2. Instead, an LP contamination of PG and present in most PG preparations appears to be recognised by TLR2 (Travassos et al. 2004). Thus, a contamination by LP is underestimated by most studies. Farhat et al. showed that commercial LPS preparations but not ultra-pure LPS preparations from E. coli are recognised by boTLR2- and boTLR1-transfected cells (in preparation; Fig. 2), although all LPS preparations tested, including the ultra-pure LPS, proved to be agonists of TLR4. These authors concluded that LP contaminations are widespread and may confuse interpretation of the results. It has been suggested that TLR2 is not a promiscuous receptor for gram-positive bacteria and many blood-borne parasites; instead, its heterodimers are receptors for the recognition of di- or triacylated LP and LPcontaminated preparations (Zähringer et al. 2008). TLR10, which is expressed in humans, is closely related to TLR-1 and 6, and appears to also recognize triacylated LP, but the signaling mechanisms are apparently different for the TLR1/ 2 and TLR-2/10 heterocomplexes (Guan et al. 2010).

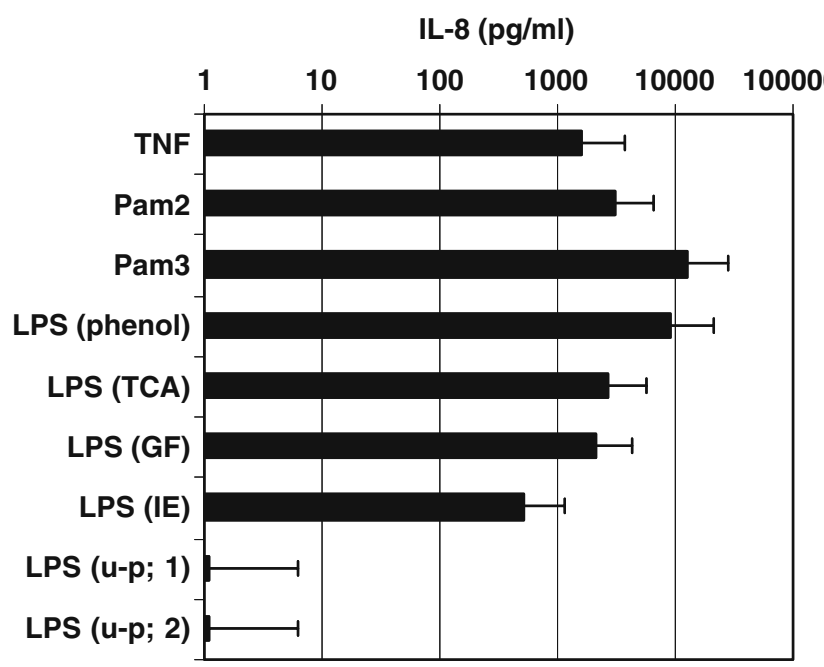

Fig. 2 The production of IL- 8 by HEK293 cells stably transfected with both boTLR1 and boTLR2 and stimulated with $100 \mathrm{nM}$ of either commercial or ultra-pure $(u-p) L P S$ from $E$. coli. The numbers 1 and 2 refer to two lots of LPS kindly provided by Dr. H. Brade, Borstel Research Center. Commercial LPS include LPS from E. coli and purified by phenol extraction (phenol), precipitated by trichloroacetic acid $(T C A)$, purified by gel filtration $(G F)$ or by isoelectric focussing (IE). Controls were transfected cells stimulated by $10 \mathrm{mM} \mathrm{TNF}$, $100 \mathrm{mM}$ dipalmitoylated (Pam2) or $100 \mathrm{mM}$ tripalmitoylated (Pam3) cysteyl-seryl-lysyl-lysyl-lysyl-lysine $\left(\mathrm{CSK}_{4}\right)$. IL-8 production was measured $24 \mathrm{~h}$ after stimulation, and means $\pm 2 \mathrm{SD}$ were plotted. The graph shows a representative experiment
Signaling through TLR (see Pierce (2010) in this special issue for details)

After discovery of the TLR system, a lot of effort went into characterizing its signaling pathways (Kaisho and Akira 2006). It is amazing how conserved these are, as the one for Toll in Drosophila and the most widespread signaling pathway in mammals are homologous to each other. Whereas TLR2 forms heterodimers with TLR1 or TLR6, and TLR4 probably forms multimeric complexes, upon engagement, it is not clear whether TLR3, TLR5, and TLR 7-9 also require multimerization for activating a signal transduction chain, At least in the case of TLR9, evidence for an allosteric effect has been provided (Latz et al. 2007). What is, however, clear is that all TLR contain a Tollinterleukin-1-receptor (TIR) domain that binds another intracellular adapter protein, called MyD88, with the exception of TLR3. In the case of all known TLR members except TLR3, the engagement/activation of MyD88 results in activation of the kinase IRAK-4 (interleukin-1-receptor associated kinase number 4) which phosphorylates/activates IRAK-1, leading to Traf6 (TNF receptor-associated factor number 6) activation. This ultimately results in the cleaving of the NF-kB-IkB complex. Whereas I $k B$ is phosphorylated and degraded, the liberated NF- $\mathrm{KB}$ has access to the nucleus where it acts as a transcription factor, resulting in the upregulation and/or induction of many host defense-related genes. TLR 2 and TLR 4 engagement preferentially use a TIR adapter molecule other than MyD88, namely Mal, in order to activate NFKB. In the case of TLR3, the activated TIR domain interacts with still another intracellular adapter molecule called TRIF, resulting in the induction of type-1 interferon (IFN). In the case of TLR4, one of five TIR adaptors (MyD88, Mal, TRIF, TRAM, SARM; see review of Kenny and O'Neill 2008) can be activated which culminates in both nuclear translocation of NF-kb and induction of IFN. IFN is exported and binds to its receptor (IFNAR) of producing and/or neighboring cells, which induces the production of more type-1 IFN. Thus, both signaling cascades lead either to activation of NFKB (all mammalian TLR members except TLR3) or to type-I-IFN induction (mammalian TLR3 and 4). NF-KB is associated with the induction of many genes having a role in immunity, and in the activation of prominent cytoplasmatic enzymes (Remer et al. 2003), up-regulation of surface-expressed molecules and induction of dendritic cell maturation. The latter protects neighboring target cells from viral infection. Type-1 IFN is antiviral, but whether it also has a protective effect in bacterial infections is controversial. The older literature also ascribes to type 1 IFN a protective role in bacterial (e.g., listerial) infections. There are three more recent papers suggesting that type-1 IFN has a harmful effect in listerial infection (Auerbuch et al. 2004; Carrero et al. 2004; 
O'Connell et al. 2004). Whether this can be generalized to any bacterial infection is an open question.

Recently, it was found that certain factors limit a TLR2or TLR4-mediated NF- $\mathrm{KB}$ activation. The first molecule identified in such an inhibitory loop was Tollip (Burns et al. 2000). The Tollip molecule phosphorylated by IRAK1 ubiquitinylates IRAK1, thereby marking it for degradation by the proteosomal degradation pathway and producing less free NF-KB.

\section{Approaches to be taken to study the TLR system in domestic animals}

In the following, it will be summarized which methods are generally used, and are most successful when studying TLR members of domestic animals. These include reverse transcription-polymerase-chain-reaction (RT-PCR) both in its classical form and the more quantitative real time-RTPCR (qRT-PCR) form, transfection, flow cytometry, immunohistochemistry (IHC), electron-microscopic immunocytochemistry (EMICC), and stimulation in vitro by putative TLR agonists. The sequencing, which of course is very important, is not especially mentioned.

\section{RT-PCR and qRT-PCR}

If part of the nucleotide sequence of the TLR member concerned is available, one can use either RT-PCR or qRTPCR to look for expression of the TLR member concerned at the mRNA level. This method is meaningful, particularly for purified cells in solution (e.g., blood cells), or for tissues available in highly purified form. It does not consider the heterogeneity with regard to tissue and cell content of organs. The expression of a given TLR member by heterogenous tissue requires IHC or EM-ICC in order to identify the tissue concerned, which means that antibodies must be available (see below), or in situ hybridization, which is not sensitive enough. The study of the expression of the TLR system in various tissues is therefore in its infancy.

\section{Transfection}

If the whole coding sequence of a given TLR member is available, one can clone the TLR in question and make DNA constructs to be used for transfection. Usually, in cells not expressing a certain trait but acquiring it when the cDNA is transfected, it can be measured whether TLRmediated activation of cells is co-transfected. Care has to be taken in interpreting the data since the recipient cell may express endogenous TLR members heterodimerizing with the transfected TLR member, thereby activating the cell line in the presence of an appropriate MAMP. For example, bovine TLR2 transfected alone was active upon stimulation of the cells with diacylated lipopeptides, but it was suspected that transfected bovine TLR2 heterodimerized with endogenous (human) TLR6 in the HEK293 cells studied (Farhat et al. 2008, 2010). This promising approach has been taken up by several groups (e.g., Schwarz et al. 2007; Yang et al. 2008; Farhat et al. 2008).

\section{Anti-TLR antibodies}

If TLR-specific antibodies are available, one can localize expression of the TLR member concerned, for example using flow cytometry, IHC or EMICC. Various TLRspecific antibodies, including monoclonals, are sold commercially, and they recognize specifically TLR members. Sadly enough, not many of these are useful for studying the TLR system of domestic animals. This could have two reasons: (1) due to the large degree of conservation, not enough antigenic differences between the species of antibody induction and the antigen chosen is observed; (2), and more likely, due to the focusing on the study of the murine and the human TLR system, domestic animal species have the role of a Cinderella and are insufficiently investigated. A study of Burgener and Jungi (2008) provided evidence that commercial antibodies recognizing, with high affinity, human TLR and useful in flow cytometry, also cross-react with canine TLR. By immunizing rabbits with peptides derived from canine TLR members, a specific staining of canine mesenterial lymph node was obtained, and it is suggested that these represent the canine variant of TLR members (Fuog et al., submitted). Thus, polyclonal antibodies against TLR members of domestic animals can be made. The laboratory of Dominguez was successful in generating monoclonals specific for porcine TLR2 (Alvarez et al. 2008). Unfortunately, this monoclonal failed to recognize bovine cells (Jungi and Dominguez, unpublished). Others were successful in generating polyclonal pig TLR2specific (Tohno et al. 2005a) and pig TLR9-specific antibodies (Shimosato et al. 2005). Due to a lack of antibodies specific for TLR members of domestic animals, one often resorts to quantitative real-time RT-PCR to study the expression of TLR members (see below). As outlined below, for most species, complete or partial coding sequences of the most important TLR members are known.

Cultivation of cells in the presence of TLR agonists

Cells expressing TLR (either autochthonous or transfected) are stimulated with highly purified agonists of TLR [LPS, synthetic diacylated or triacylated LP, poly(I:C), single 
stranded or double-stranded RNA, CpG DNA] or growtharrested whole gram-positive or gram-negative bacteria (Farhat et al. 2008), and induction of an appropriate effector function is measured, depending on the cells stimulated. This can range from measurement of a cytokine by ELISA, up-regulation of transfected surface molecules such as ELAM-1 by flow cytometry (Schwandner et al. 1999), to any other function whose expression in the cells studied is TLR-dependent.

\section{Analysis of TLR in domestic animals}

Being a conserved system, it is clear that one cannot expect dramatic inter-species changes for the TLR system, as most domestic animal species are mammals. However, in evolutionary terms, interesting observations were made in birds, in teleostean fishes and in lamprey. The review of Turin and Riva (2008) also alluded to some of these species. To allow an estimation on evolutionary dynamics, homologies of DNA of genes are indicated.

\section{Guinea pig}

In the guinea pig, TLR2, 3, 4, 7 and 8 have been worked on (Kuno et al. 2009; Astakhova et al. 2009; Kawahara et al. 2001). This is a species of lesser importance in present-day immunology. Nevertheless, one of the first studies using a pharmacological TLR4 antagonist has been reported in this species (Kuno et al. 2009).

\section{Rabbit}

Only TLR3, 4, and 7 have been addressed by researchers of rabbits (Astakhova et al. 2009; Zhou et al. 2007), as this is also a species of lesser interest in present-day immunology.

\section{Cattle}

This is one of the well-investigated species of domestic animals. Thus, the complete coding sequence of TLR1-10 is known (Menzies and Ingham 2006; Seabury et al. 2007, 2010; Turin and Riva 2008), with genes mapped to chromosomes (McGuire et al. 2006). Research has addressed additional questions such as the degree of polymorphism (see below). The nucleotide homology to human TLR genes is, on average, $65-77 \%$, and $98 \%$ to the closely related nilgai or water buffalo genes in the same subfamily (amino acid similarity is $97 \%$; Turin and Riva 2008). This enabled Vaharan et al. (2008) to establish primers for assessing nilgai TLR mRNA and to study expression by RT-PCR of TLR genes in various nilgai organs.

\section{Small ruminants}

The sheep genome was found to contain, as is typical for mammals, TLR1-10 and partial coding sequences are available for sheep (Menzies and Ingham 2006; Bhide et al. 2009; Chang et al. 2009; Turin and Riva 2008). It was reported to express the "human" rather than the "murine" type of TLR members (Nalubamba et al. 2007). Primers of ovine TLR to be used in qRT-PCR were published, based on partial sequences (Menzies and Ingham 2006), and expression in various tissues has been reported (Table 1). For both ovine TLR7 and 8, two variant genotypes are available. For all TLR genes in the ovine genome, the homology to bovine orthologues is $>95 \%$.

Based on the high degree of relatedness between sheep and goat, Tirumurugaan et al. (2010) succeeded in defining primers available for RT-PCR of goat TLR1-10 and in measuring the level of expression in various tissues (Table 1). Sequencing the amplified products revealed, as was expected, that there is a close match between ovine and caprine TLR (Tirumurugaan et al. 2010).

\section{Pig}

Genes expressing all TLR members known in humans and porcine MyD88 have been cloned (Bergman et al. 2010; Astakhova et al. 2009; Shinkai et al. 2006a; Bailey 2009; Tohno et al. 2007; Turin and Riva 2008) showing a nucleotide homology of DNA of $65-77 \%$ with human TLR orthologues. The gene coding for porcine MyD88 is $87 \%$ homologous to the human MyD88 gene.

\section{Horse}

Equine TLR2, 3, 4, 5, 7 and 8 have been fully sequenced (Turin and Riva 2008; Astakhova et al. 2009). For TLR9, part of the sequence is known, allowing qRT-PCR to be performed (Schneberger et al. 2009; Sharma and Maheshwari 2009). Compared with human TLR genes, the equine counterparts have a nucleotide homology of $65-77 \%$.

\section{Cat}

In the cat, the first 9 TLR members have been partially cloned and sequenced, and the genes have been analyzed (Ignacio et al. 2005; Turin and Riva 2008). Again, compared with human TLR genes, homology is somewhere between 65 and 77\% (TLR4) and 90\% (TLR9).

\section{$\operatorname{Dog}$}

Complete cDNA sequences are available only for TLR2, 4, and 9 (Asahina et al. 2003; Hashimoto et al. 2005; Ishii 
Table 1 Expression of TLR members by various organs from mammalian domestic animal species

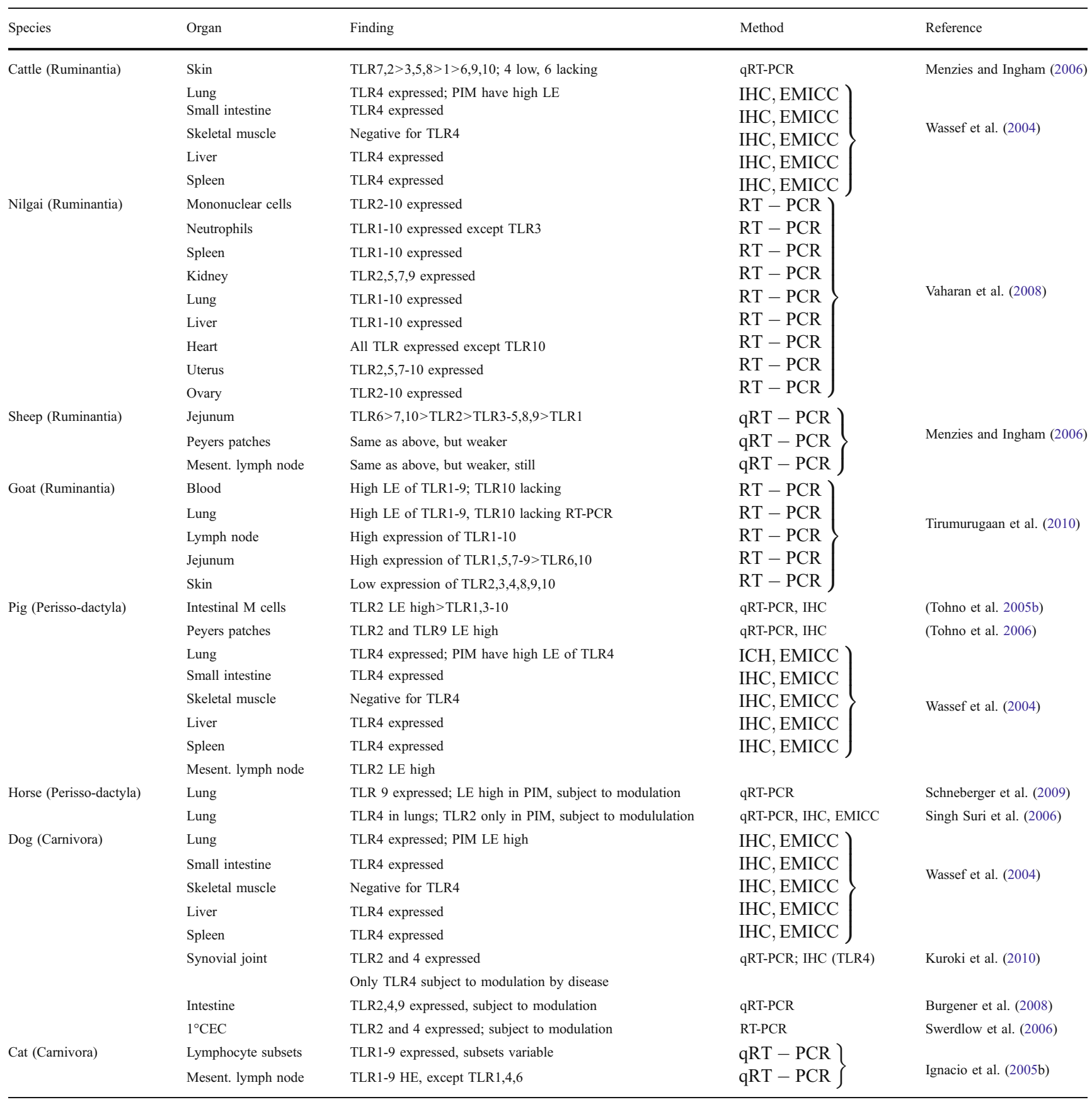

qRT-PCR Quantitative real-time reverse transcription-polymerase chain reaction, PIM pulmonary intravascular macrophages, $L E$ level of expression, IHC immunohistochemistry (includes detection by fluorescence), EMICC electron microscope immunocytochemistry, $R T-P C R$ reverse transcription-polymerase chain reaction, mesent. mesenteric, $C E C$ colonic epithelial cells.

et al. 2006). Compared with human TLR genes, the nucleotide homology is between 65 and $77 \%$ (TLR4) or $88 \%$ (TLR2, 9).

\section{Birds}

We are now coming to non-mammalian species. Due to the larger distance to any given mammal, the phylogenetic aspect of a system putatively being under evolutionary pressure becomes more obvious (Temperley et al. 2008). The new names, as suggested by Temperley et al. (2008), are used. The chicken, i.e. the bird studied best, is used as representative. Some of the genes have orthologues in mammals (TLR3, 4, 5, 7), while TLR8 and TLR9 are lacking, and the mammalian TLR1, 6 and 10 being in mammals on the same chromosome are replaced by 
TLR1LA and LB, and so is TLR2, replaced by TLR2A and TLR2B as a result of gene duplication. There is also TLR15 (unique to birds) and TLR21 (shared with fishes). Chicken TLR21 is an innate CpG DNA receptor distinct from mammalian TLR9 (Brownlie et al. 2009; Keestra et al. 2010). In the zebra finch, an additional gene duplication occurred in TLR7 (Brownlie et al. 2009). Thus, the recognition spectrum of PAMP.is almost identical in birds and mammals.

As far as downstream signaling is concerned, the MyD88-mediated pathway appears to be expressed, but the TRIF-TRAM-mediated pathway may be missing (Keestra and van Putten 2008). This has been related to markedly lower sensitivity to LPS of birds compared to mammals.

Interestingly, linkage analyses suggested that certain forms of chicken TLR4 are associated with resistance/ suseptibility to systemic infection of young chickens with Salmonella enterica serovar Typhimurium (Leveque et al. 2003).

\section{Teleostean fishes}

Despite their high degree of variation, teleostean fishes all have a similar TLR system and share functional properties with those of mammals in principle, but some distinct features are noted (Rebl et al. 2010). Bony fishes tend to have more TLR members than mammals. In approximately a dozen teleostean species, 17 TLR members were found (TLR1, 2, 3, 4, 5, 6, 7, 8, 9, 13, 14, 18, 19, 20, 21, 22, 23) (Rebl et al. 2010). They may be grouped in 6 major families (TLR1/2, 3, 4, 5, 7, 11) (Roach et al. 2005). There is also a soluble TLR5 variant (designated TLR5S). The TLR7 family comprises TLR9 that has specificity for CpG DNA rather than single-strand RNA, as have other representatives of this group. In some fish species, there is extensive gene duplication (e.g., TLR8.1 and TLR8.2), and use of different splice variants (e.g., TLR9.1 and TLR9.2). The two-digit TLR members are within the TLR11 family except TLR-14 (TLR-1/2 family; Roach et al. 2005), and they are referred to as "fish TLR", as this order experienced extensive gene duplication in some teleost species, whereas in the mouse, it is represented by murine TLR 11,12 and 13 only, and in humans, there is only a pseudogene of TLR22. TLR22 has been shown in the fugu (Takifugu rupripes) to induce type-1-IFN, thereby being a functional analog of TLR3. As stated above, a PAMP at the molecular level is not known for this family in mammals. Quite clearly, there are more gene duplications in teleosts than in mammals, and the redundancy appears to be higher.

It has been pointed out by Rebl et al. (2010) that these TLR, in order to function like mammalian TLR, have to interact with down-stream signal transduction molecules.
There is functional evidence that piscine MyD88 is interacting with TIR domains (van der Sar et al. 2006), but the piscine IFN-activating pathway differs from the mammalian one. The Tollip molecule has also been found in teleosts either in one or several different variants (Rebl et al. 2008)

\section{Lamprey}

The Japanese lamprey genome contains 16 TLR genes, some of which are M-type ("mammalian-type"), and F-type ("fish-type"), respectively. Remarkably, neither IRF3 nor IRF7 was expressed, two essential signaling molecules in the mouse, leading to type-I-IFN production, although the upstream molecules of the signaling chain were highly conserved between lamprey and mammals (Kasmatsu et al. 2010).

\section{Functional variation of TLR in mammals}

Being a well-conserved system, one may not expect great differences in TLR functions since most domestic animals are mammals and thus are relatively close to each other in phylogeny. Nevertheless, there are some species-specific differences in ligand recognition (Werling et al. 2009; Fitzgerald et al. 2004). The lipid A analog C406 acts as an agonist for murine but as an antagonist for human TLR4 (Tamai et al. 2003). LPS from Rhodobacter sphaeroides was shown to activate horse and hamster TLR4 but not human and murine TLR4 (Lohmann et al. 2007). TLR2/6 and TLR2/1 heterodimers recognize diacylated and triacylated LP, respectively. Depending on the species, fatty acids of a maximal length of 6,12 or $14 \mathrm{C}$ atoms are recognized by the mouse, cattle or human, respectively (Farhat et al. 2010). The requirements for optimal recognition of the murine, the bovine or the human TLR9 differs between species (Zhang et al. 2001). One of the receptors for the recognition of Salmonella enterica serovar Typhimurium is TLR5 as it recognizes bacterium-derived flagellin. Chicken and mouse TLR5 were consistently more sensitive to flagellin from this organism than human TLR5, a speciesrestricted particularity controlled by one single amino acid of this type of flagellin (Keestra et al. 2008). Thus, although the TLR system is conserved in principle in mammals, some subtle species-specific variations are observed.

\section{TLR expression by various tissues}

The interface between a potential host and a microbe coming from the surroundings are either immune cells or epithelia. So, expression of TLR members must be highest 
and most varied in mononuclear phagocytes, neutrophils/ heterophils, dendritic cells and epithelial cells such as enterocytes. However, dendritic cells are not uniform, and expression levels of TLR are quite different between types of dendritic cells (Werling et al. 2006). The same applies to mononuclear cells. Several studies refer to expression of TLR members by ocular tissue (Pearlman et al. 2010; Redfern and McDermott 2010). Although it is generally assumed that a high level of expression of a given TLR member indicates an efficient response to a PAMP, the study of expression is complicated by several factors: (1) it is not always clear whether nonexisting reports on certain TLR member expression means the virtual absence of a given TLR member from this tissue or organ, or a lack of relevant tools for analysis, or simply lacking information; (2) it is difficult to delineate experimentally a threshold between scarce and lacking expression, and using RT-PCR or qRT-PCR it is difficult to estimate the level of expression at the protein level; (3) the expression levels can be modulated by various factors, e.g., cytokines or PAMP themselves (see below); and (4) in whole organs with many different tissues, it is not clear whether this means a given TLR member is highly expressed in this organ at large, or whether a high-expressing tissue (e.g., blood cells) causes this result. Nevertheless, for quick information, an attempt to summarize what is known on TLR expression levels in domestic animals is presented in Table 1, which may be consulted for getting an impression of the most important organs. Most revealing are such data if antibodies are available, allowing the study of protein expression by individual cells rather than mRNA expression of the organ at large. Therefore, the method by which a result was obtained is also given in Table 1. Most work has been done on TLR2 and TLR4, as these are regarded as major PRR for gram-positive and -negative bacteria, respectively. As the TLR system is conserved, in mammals, one may, as a first estimate, extrapolate from one species to another. Looking at Table 1, it is surprising that both partners of heterodimers are not always coexpressed, i.e. that TLR2 may be expressed, but neither TLR1 nor TLR6.

TLR4, the best-studied TLR member, appears to be expressed in various species (pig, dog, cattle) by macrophages and epithelial cells of the normal lung, small intestine, liver, spleen, kidney, cornea, but not in the normal skin and in skeletal muscles (Wassef et al. 2004; Tirumurugaan et al. 2010). For details, the reader is referred to Turin and Riva (2008).

The laboratory of Baljit Singh succeeded in assessing expression of TLR2, 4 and 9 in the unstimulated horse lung (Singh Suri et al. 2006; Schneberger et al. 2009). Moreover, they had antibodies crossreacting with equine TLR4. That TLR2 is expressed in pulmonary vascular macrophages exclusively is based on circumstantial evidence. Also, for
TLR4. the level of expression was higher in PIM than in other lung cells.

Quite recently, evidence for expression of TLR2, 4 and 9 was reported for a porcine cell line (IPEC-J2) (Burkey et al. 2009). Another study showed that porcine TLR2 is expressed by intestinal M cells (Tohno et al. 2005b), and that TLR9 is also expressed in swine Peyer's patches (Tohno et al. 2006). These authors had access to TLR2specific and TLR9-specific polyclonal antibodies (Tohno et al. 2005b; Shimosato et al. 2005).

\section{Modulation of TLR expression and activity}

Under modulation, we understand up- or down-regulation of TLR expression and function. There are several ways how to modulate TLR expression: (1) specific modulation by TLR agonists; (2) specific modulation of other immunerelated parameters as a result of TLR triggering; (3) nonspecific modulation of TLR expression by any compound, or by the underlying disease; and (4) induction of regulatory $T$ cells $\left(T_{\text {reg }}\right)$ (Nyirendra et al. 2009). A word of warning is also appropriate here. It may be that the level of expression and the function are dissociated. Thus, we observed in bovine mononuclear cells expression of both TLR2 and TLR4, but the levels of expression were uninfluenced by IFN- $\gamma$, quite in contrast to their response to LPS (Jungi and Sauter, unpublished).

In the study reported on dogs with chronic enteropathies (Burgener et al. 2008), there is a general upregulation of TLR2 and TLR4. McMahon et al. (2010) also showed that, in inflammatory bowel disease of the dog, there is an upregulation of TLR2 in the duodenum, and regarding upregulation of TLR4, there was a definitive trend but levels of significance were not reached (McMahon et al. 2010). In the latter study, more mildly ill dogs were enrolled than in the former. In dogs with oligoarthritis and degenerative cranial cruciate ligament rupture, the expression of several genes involved in immune responses, among these TLR2 and 9, were found to be elevated on synovial cells (Muir et al. 2007), although there was wide variation. What is surprising in this study is that a comparison with healthy dogs was made, which have a very small volume of synovial fluid and a low number of synovial cells.

In the dog, both TLR2 and 4 appear to be expressed weakly by normal colonic epithelial cells, and they are dramatically up-regulated by prior treatment of the cells with the respective MAMP (Swerdlow et al. 2006). In cattle and horses, TLR2 and TLR4 were up-regulated after exposure to LPS or TLR2 ligands (Ibeagha-Awemu et al. 2008; Singh Suri et al. 2006). A study suggested that activation of TLR3, but not TLR4, leads to increased resistance to infection with porcine reproductive and 
respiratory syndrome virus (PRRSV) (Akashi et al. 2000). In some cases, specific stimulation by a TLR agonist has a tolerizing effect. For example, stimulation of TLR5 by Salnonella flagellin results in tolerization of these and in blockade of NF-kB-mediated gene induction (Sun et al. 2007). Prolonged or repeated stimulation of TLR5 also leads to their refractoriness. Similarly, prior exposure of human epithelial cells to flagellin of Pseudomonas aeruginosa tolerized these in that a subsequent TLR5 stimulation by $P$. aeruginosa no longer had a deleterious effect, and the innate and potentially harmful response was weakened (Kumar et al. 2007). That TLR engagement may be counterproductive has been shown by Lang et al. (2005). It has been found that expression in the pancreas of an antigen to which all transgenic cytotoxic $\mathrm{T}$ cells are specific is not attacked (Ohashi et al. 1993), but when infected with the virus (Ohashi et al. 1993), when applying TNF (Ohashi et al. 1993) or when stimulating the TLR system (Lang et al. 2005), tolerance is broken, and autoimmune disease - in this case diabetes - results. Using porcine reproductive and respiratory syndrome virus (PRRSV), it was shown that infection with this virus led to a reduction of LTA-induced IL-1 production and LTA- or LPS-induced IL-6 production by macrophages (Chaung et al. 2008; Liu et al. 2009). Furthermore, infection of bovine alveolar macrophages with $M$. bovis may silence other TLR-related signaling pathways, and may induce some sort of cross-tolerance induction to other PAMP, similar to that described for other species (Piercy et al. 2007).

The expression of 9 TLR members was studied in various feline tissues with a view to investigating modulation by infection with feline immunodeficiency virus (FIV) (Ignacio et al. 2005). A complex pattern of up- or downregulation induced by FIV for all members of the TLR family was obtained.

Considering that there are roughly 10 domestic animal species, about 10 TLR members, 20 or so tissues to be analyzed, and many potentially modulatory treatments, one grasps immediately that the information available on modulation is sketchy, at best. But diseases are speciesspecific. It makes sense that one has studied preferentially modulation of TLR expression by disease and their therapy.

\section{TLR and diseases}

When the Bern laboratory started working on TLR of domestic animals, there was the theoretical concept of TLR as PRR (Werling and Jungi 2003). But there was no recognized disease associated with a dysregulation of TLR members or TLR signaling. This has dramatically changed. We now know that modulating either TLR expression or TLR-mediated function may alter both innate and adaptive immune reaction. This knowledge can be utilized not only in vaccination protocols to optimize immunostimulatory effects of antigens but also in other situation, e.g., in the control of allergies.

Allergic diseases are governed by a Th2 response, and triggering of TLR favors a Th1 response, thereby inhibiting allergic reactions and other Th2-mediated responses (see review of Gangloff and Guenounou 2003). Although it may not be possible to identify a defunct TLR member or signalling compound, a tolerization of the TLR system occurs, e.g., due to previous stimulation of the TLR system. Alternatively, TLR stimulation may lead to the induction of $\mathrm{T}_{\text {reg }}$ and dampens an adaptive immune response. Examples of this kind are numerous and are summarized by Nyirendra et al. (2009).

\section{TLR polymorphisms}

Here, domestic animals might provide some interesting clues as pathogens cause, in most cases, a species-specific health problem, and it is the coevolution of host and pathogen that shaped TLR sequences, particularly the extracellular, leucine-rich repeats (LRR). The cases reported are not as clearcut as in the case of the $\mathrm{C} 3 \mathrm{H} / \mathrm{HeJ}$ mouse which contains a missense mutation, rendering the response to LPS an all-or-none question (Poltorak et al. 1998). Nevertheless, cases of an inheritable trait favoring certain diseases have been reported, and we can still learn from non-synonymous single nucleotide polymorphism (NSSNP), although the pathogen(s) shaping TLR LRR is/ are most often unknown. The proportion of NSSNP gives us some information as to whether a sequence is genetically stable, or whether evolution drives the amino acid sequence away from the original one. Most often, NSSNP have been listed without association of a given disease.

\section{Ruminants}

In genes of many ruminants, including TLR members and TLR-adapter proteins, NSSNP have been identified. At least 54 NSSNP in 11 bovine innate immune genes [TLR110, peptidoglycan recognition receptor number 1 (PGLYRP1)] have been identified for 37 cattle breeds, with an average polymorphic density of one alteration per 219 base pairs (Seabury et al. 2010). Interestingly, however, Bos taurus taurus and Bos taurus indicus breeds appear to have haplotype sharing at every locus. However, the actual number of NSSNP might be considerably higher (Jann et al. 2009), and may also indicate selective pressure in ruminant TLR compared to other mammalian TLR in the region necessary for ligand binding/heterodimerization (Werling et al. 2009). Whereas a direct link of such TLR- 
NSSNP in ruminants to a specific disease might be hard to obtain, a recent comarative genomic approach identified eight genes as potentially causative genes for variations of health-related traits (Jann et al. 2009). These include susceptibility to clinical mastitis in dairy cattle, general disease resistance in sheep, cattle, human and mice, and tolerance to protozoan infection in cattle and mice. Four TLR-related genes (TLR1, 6, MyD88, IRF3) appear to be the most likely candidate genes underlying quantitative trait loci (QTL) which control the resistance to the same or similar pathogens in several species (Jann et al. 2008).

Fine examples of an association between infectious disease and mutations have been reported by Bhide, Mucha and collaborators. Novel NSSNP of cattle TLR were reported, some of which were found to be associated with facilitated infection with Mycobacterium avium subsp. paratuberculosis, the causative agent of Johne's disease (Mucha et al. 2009). In sheep, there was also an association between novel NSSNP in TLR1 and TLR2 and the severity of infection with Mycobacterium avium subsp. paratuberculosis (Bhide et al. 2009).

\section{Pig}

In the pig, 21, 11, 7 and 13 NSSNP were found in TLR 2, 4, 5 and 6, respectively, many of which are in the extracellular LRR (Shinkai et al. 2006b). The biased distribution suggests that these NSSNP are the result of coevolution of host and certain unknown pathogens, Despite intensive breeding, heterozygosity with regard to TLR is apparently an advantage. In another porcine study, TLR1, 6 and 10 genes have been completely (re)-sequenced (Shinkai et al. 2006a). An analysis of the cytoplasmatic portion (Fig. 1) suggested that the signal transduction pathway of TLR10 is different from that of the closely related TLR1 and 6 (Shinkai et al. 2006a). This is surprising, as in the mouse and in human, TLR1, 2, 6, and 10 all express a TIR domain interacting with MyD88 and are thought to mediate NF- $\mathrm{kB}$ activation. In the latter study, six polymorphic microsatellite markers within the genetic regions of TLR1, 6 and 10 were developed as they might be useful in association studies of TLR variants and resistance to disease. According to a more recent study, in the genes coding for porcine TLR1, 2 and 6, a total of 20, 26 and 27 NSSNP were found, respectively (Bergman et al. 2010).

\section{Horse}

In the horse, a total of 13 SNP were found in TLR3, 7 and 8 (Astakhova et al. 2009). Allelic frequencies were determined in 154 horses belonging to 5 different breeds. A comparison with TLR3, 7 and 8 from other mammals revealed several conserved regions within the variable LRR. This is in line with an earlier study specifically looking at TLR4 and showing a restricted degree of polymorphism in horse TLR4 (Vychodilova-Krenkova et al. 2005).

\section{Concluding remarks}

A lot of information has been generated from the study of either the murine or the human TLR system, since these species appear to be the most interesting and the most accessible. The tacit assumption that the TLR system in all higher vertebrates is alike roots in two facts. Firstly, not many tools exist for the study of the TLR system of domestic animal species. Although working in principle in several species, the use of the knockout technology, which was essential for progress, favors to study the TLR system in mice. Humans are more interesting than domestic animal species for researchers and their sponsors. Secondly, given the fact that the TLR system is locked by both MAMP recognition and interaction with signaling molecules, which have been conserved, this system could not deviate a lot in evolutionary terms, which provides a rationale for comparing chickens, fishes and mammals in order to learn more about evolutionary constraints. Nevertheless, since recognition by the TLR system is associated with adaptive immunity, by learning more about the TLR system in domestic animals, one might learn more about adjuvants in vaccines, as the TLR system provides optimal immunostimulation. In other words, if it is understood how to stimulate maximally the TLR system may be the key to immunize optimally. Therefore, to study domestic animal species with regard to the TLR system might not only tell us about the constraints imposed by pathogens of a given species; it also might provide an optimal vaccine regime in the species studied.

\section{References}

Akashi S, Ogata H, Kirikae F, Kirikae T, Kawasaki K, Nishijima M, Shimazu R, Nagai Y, Fukudome K, Kimoto M, Miyake K (2000) Regulatory roles for CD14 and phosphatidylinositol in the signaling via toll-like receptor 4-MD-2. Biochem Biophys Res Commun 268:172-177

Akira S, Takeda K, Kaisho T (2001) Toll-like receptors: critical proteins linking innate and acquired immunity. Nat Immunol 2:675-680

Alexopoulou L, Holt AC, Medzhitov R, Flavell RA (2001) Recognition of double-stranded RNA and activation of NF-kappaB by Toll-like receptor 3. Nature 413:732-738

Alvarez B, Revilla C, Doménech N, Pérez C, Martinez P, Alonso F, Ezquerra A, Dominguez J (2008) Expression of toll-like receptor 2 (TLR2) in porcine leukocyte subsets and tissues. Vet Res 39:13 
Anderson KV, Bokla L, Nusslein-Volhard C (1985) Establishment of dorsal-ventral polarity in the Drosophila embryo: the induction of polarity by the Toll gene product. Cell 42:791-798

Asahina Y, Yoshioka N, Kano R, Morimoto T, Hasegawa A (2003) Full-length cDNA cloning of Toll-like receptor 4 in dogs and cats. Vet Immunol Immunopathol 96:159-167

Astakhova NM, Perelygin AA, Zharikk AA, Lear TL, Coleman SJ, MacLeod JN, Brinton MA (2009) Characterization of equine and other vertebrate TLR3, TLR7, and TLR8 genes. Immunogenetics 61:529-539

Auerbuch V, Brockstedt DG, Meyer-Morse N, O'Riordan M, Portnoy DA (2004) Mice lacking the type I interferon receptor are resistant to Listeria monocytogenes. J Exp Med 200:527-533

Bailey M (2009) The mucosal immune system: recent developments and future directions in the pig. Dev Comp Immunol 33:375-383

Bergman IM, Rosengren JK, Edman K, Edfors I (2010) European wild boars and domestic pigs display different polymorphic patterns in the Toll-like receptor (TLR) 1, TLR2, and TLR6 genes. Immunogenetics 62:49-58

Beutler B, Jiang Z, Georgel P, Crozat K, Croker B, Rutschmann S, Du X, Hoebe K (2006) Genetic analysis of host resistance: Toll-like receptor signaling and immunity at large. Annu Rev Immunol 24:353-389

Bhide MR, Mucha R, Mikula I Jr, Kisova L, Skrabana R, Novak M, Mikula I Sr (2009) Novel mutations in TLR genes cause hyporesponsiveness to Mycobacterium avium subsp. paratuberculosis infection. BMC Genet 10:21

Brownlie R, Zhu J, Allan B, Mutwiri GK, Babiuk LA, Potter A, Griebel P (2009) Chicken TLR21 acts as a functional homologue to mammalian TLR9 in the recognition of $\mathrm{CpG}$ oligodeoxynucleotides. Mol Immunol 46:3163-3179

Burgener IA, Jungi TW (2008) Antibodies specific for human or murine toll-like receptors detect canine leuocytes by flow cytometry. Vet Immunol Immunopathol 124:184-191

Burgener IA, König A, Allenspach K, Sauter SN, Boisclair J, Doherr MG, Jungi TW (2008) Upregulation of toll-like receptors in canine chronic enteropathies. J Vet Int Med 22:553-560

Burkey TE, Skjolaas KA, Dritz SS, Minton JE (2009) Expression of porcine Toll-like receptor 2,4 and 9 gene transcripts in the presence of lipopolysaccharide and Salmonella enterica serovars Typhimurium and Choleraesuis. Vet Immunol Immunopathol 130:96-101

Burns K, Clatworthy J, Martin L, Martinon F, Plumpton C, Maschera B, Lewis A, Ray K, Tschopp J, Volpe F (2000) Tollip, a new component of the IL-1RI pathway, links IRAK to the IL-1 receptor. Nat Cell Biol 2:346-351

Carrero JA, Calderon B, Unanue ER (2004) Type I interferon sensitizes lymphocytes to apoptosis and reduces resistance to Listeria infection. J Exp Med 200:535-540

Chang JS, Russel GC, Jann O, Glass EJ, Werling D, Haig DM (2009) Molecular cloning and characterization of Toll-like receptors 110 in sheep. Vet Immunol Immunopathol 127:94-105

Chaung HC, Chen CW, Hsieh BL, Chung WB (2008) Toll-like receptor expressions in porcine alveolar macrophages and dendritic cells in responding to poly IC stimulation and porcine reproductive and respiratory syndrome virus (PRRSV) infection. Comp Immunol Microbio Infect Dis:197-213

Farhat K, Sauter KS, Brcic M, Ulmer AJ, Frey J, Jungi TW (2008) The response of HEK293 cells transfected with bovine TLR2 to established pathogen-associated molecular patterns and to bacteria causing mastitis in cattle. Vet Immunol Immunopathol 125:326336

Farhat K, Riekenberger S, Jung G, Wiesmueller K-H, Jungi TW, Ulmer AJ (2010) Identification of full length bovine TLR1 and functional characterization of lipopeptide recognition by bovine TLR2/1 heterodimer. Vet Res 41 (in press)
Fitzgerald KA, Rowe DC, Golenbock DT (2004) Endotoxin recognition and signal transduction by the TLR4/MD2-complex. Microbes Infect 6:1361-1367

Gangloff SC, Guenounou M (2003) Toll-like receptors and immune response in allergic disease. Clin Rev Allergy Immunol 26:115125

Gewirtz AT, Navas TA, Lyons S, Godowski PJ, Madaras JL (2001) Cutting edge: bacterial flagellin activates basolaterally expressed TLR5 to induce epithelial proinflammatory gene expression. J Immunol 167:1882-1885

Guan Y, Ranoa DR, Jiang S, Muthu SK, Li X, Baudry J, Tapping RI (2010) Human TLRs 10 and 1 share common mechanisms of innate immune sensing but not signaling. J Immunol 184:5094 5103

Hashimoto M, Asahina Y, Sano J, Kano R, Morimoto T, Hasegawa A (2005) Cloning of canine toll-like receptor 9 and its expression in dog tissue. Vet Immunol Immunopathol 106:159-163

Hashimoto M, Tawaratsumida K, Kariya H, Kiyohara A, Suda Y, Krikae F, Kirikae T (2006) Götz F (2006) Not lipoteichoic acid but lipoproteins appear to be the dominant immunobiologically active compounds in Staphylococcus aureus. J Immunol 177:3162-3169

Hayashi F, Smith KD, Ozinsky A, Hawn TR, Yi EC, Goodlett DR, Eng JK, Akira S, Underhill DM, Aderem A (2001) The innate immune response to bacterial flagellin is mediated by Toll-like receptor 5. Nature 410:1099-1103

Heil F, Hemmi H, Hochrein H, Ampenberger F, Kirschning C, Akira S, Lipford G, Wagner H, Bauer S (2004) Species-specific recognition of single-stranded RNA via toll-like receptor 7 and 8. Science 303:1526-1529

Hemmi H, Takeuchi O, Kawai T, Kaisho T, Sato S, Sanjo H, Matsumoto M, Hoshino K, Wagner H, Takeda K, Akira S (2000) A Toll-like receptor recognizes bacterial DNA. Nature 408:740-745

Ibeagha-Awemu EM, Lee JW, Ibeagha AE, Bannerman DD, Paape MJ, Zhao X (2008) Bacterial lipopolysaccharide induces increased expression of toll-like receptor (TLR) 4 and downstream TLR signaling molecules in bovine mammary epithelial cells. Vet Res 39:11-22

Ignacio G, Nordone S, Howard KE, Dean GA (2005) Toll-like receptor expression in feline lymphoid tissues. Vet Immunol Immunopathol 106:229-237

Ishii M, Hashimoto M, Oguma K, Kano R, Morimoto T, Hasegawa A (2006) Molecular cloning and tissue expression of canine Tolllike receptor 2 (TLR2). Vet Immunol Immunopathol 110:87-95

Jann OC, Werling D, Chang JS, Haig D, Glass EJ (2008) Molecular evolution of bovine Toll-like receptor 2 suggests substitutions of functional relevance. BMC Evol Biol 20:16-31

Jann OC, King A, Corrales NL, Anderson SI, Jensen K, Ait-Ali T, Tang H, Wu C, Cockett NE, Archibald AL, Glass EJ (2009) Comparative genomics of Toll-like receptor signalling in five species. BMC Genomics 10:216-230

Kaisho T, Akira S (2006) Toll-like receptor function and signaling. J Allergy Clin Immunol 117:979-987

Kanzok SM, Hoa NT, Bonizzoni M, Luna C, Huang Y, Malacrida AR, Zheng L (2004) Origin of Toll-like receptor-mediated innate immunity. J Mol Evol 58:442-448

Kasmatsu J, Oshiumi H, Matsumoto M, Kasahara M, Seya T (2010) Phylogenetic and expression analysis of lamprey toll-like receptors. Dev Comp Immunol 34:855-865

Kawahara T, Kuwano Y, Teshima-Kondo S, Kawai T, Nikawa T, Kishi K, Rokutan K (2001) Toll-like receptor 4 regulates gastric pit cell responses to Helicobacter pylori infection. J Med Invest 48:190-197

Kawai T, Akira S (2006) TLR signaling. Cell Death Diff 13:816-825

Keestra AM, van Putten JP (2008) Unique properties of the chicken TLR4/MD-2 complex: selective lipopolysaccharide activation of the MyD88-dependent pathway. J Immunol 181:4354-4362 
Keestra AM, de Zoete MR, Van Bambeke F, van Putten JP (2008) Functional characterization of chicken TLR5 reveals speciesspecific recognition of flagellin. Mol Immunol 45:1298-1307

Keestra AM, de Zoete MR, Bouwman LI, van Putten JP (2010) Chicken TLR21 is an innate CpG DNA receptor distinct from mammalian TLR9. J Immunol:460-467

Kenny EF, O'Neill LAJ (2008) Signalling adapters used by Toll-like receptors: an update. Cytokine 43:342-348

Kumar A, Yin J, Zhang J, Yu FS (2007) Modulation of corneal epithelial innate immune response to pseudomonas infection by flagellin pretreatment. Invest Ophthalmol Vis Sci 48:4664-4470

Kuno M, Nemoto K, Ninomiya N, Inagaki E, Kubota M, Matsumoto T, Yokota H (2009) The novel selective toll-like receptor 4 signal transduction inhibitor tak-242 prevents endotoxaemia in conscious guinea-pigs. Clin Exp Pharmacol Physiol 36:589-593

Kuroki K, Stoker AM, Sims HJ, Cook JL (2010) Expression of Tolllike receptors 2 and 4 in stifle joint synovial tissues of dogs with or without osteoarthritis. Am J Vet Res 71:750-754

Lang KS, Recher M, Junt T, Navarini AA, Harris NL, Freigang S, Odermatt B, Conrad C, Ittner LM, Bauer S, Luther SA, Uematsu S, Akira S, Hengartner H, Zinkernagel RM (2005) Toll-like receptor engagement converts T-cell autoreactivity into overt autoimmune disease. Nat Med 11:138-145

Latz E, Verma A, Visintin A, Gong M, Sirois CM, Klein DC, Monks BG, McKnight CJ, Lamphier MS, Duprex WP, Espevik T, Golenbock DT (2007) Ligand-induced conformational changes allosterically activate Toll-like receptor 9. Nat Immunol 8:772-779

Lemaitre B, Nicolas E, Michaut L, Reichhart JM, Hoffmann JA (1996) The dorsoventral regulatory gene cassette spatzle/Toll/ cactus controls the potent antifungal response in Drosophila adults. Cell 86:973-983

Leveque G, Forgetta V, Moroll S, Smith AL, Bumstead N, Barrow P, Loredo-Osti JC, Morgan K, Malo D (2003) Allelic variation in TLR4 is linked to susceptibility to Salmonella enterica serovar Typhimurium infection in chickens. Infect Immun 71:1116-1124

Liu CH, Chaung HC, Chang HL, Peng YT, Chung WB (2009) Expression of Toll-like receptor mRNA and cytokines in pigs infected with porcine reproductive and respiratory syndrome virus. Vet Microbiol 136:266-276

Lohmann KL, Vandenplas ML, Barton MH, Bryant CE, Moore JN (2007) The equine TLR4/MD-2 complex mediates recognition of lipopolysaccharide from Rhodobacter sphaeroides as an agonist. J Endotoin Res 13:235-242

Mackey D, McFall AJ (2006) MAMPs and MIMPs: proposed classifications for inducers of innate immunity. Mol Microbiol 61:1365-1371

McGuire K, Jones M, Werling D, Williams JL, Glass EJ, Jann O (2006) Radiation hybrid mapping of all 10 characterized bovine Toll-like receptors. Anim Genet 37:47-50

McMahon LA, House AK, Catchpole B, Elson-Riggins J, Riddle A, Smith K, Werling D, Burgener IA, Allenspach K (2010) Expression of Toll-like receptor 2 in duodenal biopsies from dogs with inflammatory bowel disease is associated with severity of disease. Vet Immunol Immunopathol 135:158-163

Medzhitov R, Janeway CA Jr (1997) Innate immunity: impact on the adaptive immune response. Curr Opin Immunol 9:4-9

Medzhitov R, Preston-Hurlburt P, Janeway CA Jr (1997) A human homologue of the Drosophila Toll protein signals activation of adaptive immunity. Nature 388:394-397

Medzhitov R, Preston-Hurlburt P, Kopp E, Stadlen A, Chen C, Ghosh S, Janeway CAJ (1998) MyD88 is an adaptor protein in the hToll/IL-1 receptor family signaling pathways. Mol Cell 2:253258

Menzies M, Ingham A (2006) Identification and expression of Tolllike receptors 1-10 in selected bovine and ovine tissues. Vet Immunol Immunopathol 109:23-30
Morisato D, Anderson KV (1994) The spätzle gene encodes a component of the extracellular signaling pathway establishing the dorsal-ventral pattern of the Drosophila embryo. Cell 76:677-688

Mucha R, Bhide MR, Charkurkar EB, Novak M, ISr M (2009) Toll-like receptors TLR1, TLR2 and TLR4 gene mutations and natural resistance to Mycobacterium avium subsp. paratuberculosis infection in cattle. Vet Immunol Immunopathol 128:381-388

Muir P, Schaefer SL, Manley PA, Svaren JP, Oldenhoff WE, Hao Z (2007) Expression of immune response genes in the stifle joint of dogs with oligoarthritis and degenerative cranial cruciate ligament rupture. Vet Immunol Immunopathol 119:214-221

Nalubamba KS, Gossner AG, Dalziel RG, Hopkins J (2007) Differential expression of pattern recognition receptors in sheep tissues and leukocyte subsets. Vet Immunol Immunopathol 118:252-262

Nyirendra MH, O’Brien K, Sanvito L, Constantinescu CS, Gran B (2009) Modulation of regulatory T cells in health and disease: role of toll-like receptors. Inflamm Allergy Drug Targets 8:124 129

O'Connell RM, Saha SK, Vaidya SA, Bruhn KW, Miranda GA, Zarnegar B, Perry AK, Nguyen BO, Lane TF, Taniguchi T, Miller JF, Cheng G (2004) Type I interferon production enhances susceptibility to Listeria monocytogenes infection. J Exp Med 200:437-445

Ohashi PS, Oehen S, Aichele P, Pircher H, Odermatt B, Herrera P, Higuchi Y, Buerki K, Hengartner H, Zinkernagel RM (1993) Induction of diabetes is influenced by the infectious virus and local expression of MHC class I and tumor necrosis factor-alpha. J Immunol 150:85-94

Pearlman E, Johnson A, Adhikari G, Sun Y, Chinnery HR, Fox T, Kester M, McMenamin PG (2010) Toll-like receptors at the ocular surface. Ocul Surf 6:108-116

Pierce SK (2010) Toll-like receptors (signaling / compartimentalization). Cell and Tissue Rearch (special issue)

Piercy J, Werling D, Coffey TJ (2007) Differential responses of bovine macrophages to infection with bovine-specific and nonbovine specific mycobacteria. Tuberculosis (Edinb ) 87:415-420

Poltorak A, He X, Smirnova I, Liu MY, Huffel CV, Du X, Birdwell D, Alejos E, Silva M, Galanos C, Freudenberg M, RicciardiCastagnoli P, Layton B, Beutler B (1998) Defective LPS signaling in $\mathrm{C} 3 \mathrm{H} / \mathrm{HeJ}$ and $\mathrm{C} 57 \mathrm{BL} / 10 \mathrm{ScCr}$ mice: mutations in Tlr4 gene. Science 282:2085-2088

Rakoff-Nahoum S, Paglino J, Eslami-Varzaneh F, Edberg S, Medzhitov R (2004) Recognition of commensal microflora by toll-like receptors is required for intestinal homeostasis. Cell 118:229-241

Rebl A, Hoyheim B, Fischer U, Köllner B, Siegl E, Seyfert HM (2008) Tollip, a negative regulator of TLR-signalling, is encoded by twin genes in salmonid fish. Fish Shellfish Immunol 25:153162

Rebl A, Goldammer T, Seyfert HM (2010) Toll-like receptor signaling in bony fish. Vet Immunol Immunopathol 134:139-150

Redfern RL, McDermott AM (2010) Toll-like receptors in ocular surface disease. Exp Eye Res 90:679-687

Remer KA, Brcic M, Jungi TW (2003) Toll-like receptor-4 mediates an LPS-induced oxidative burst. Immunol Lett 85:75-80

Roach JC, Glusman G, Rowen L, Kaur L, Purcell MK, Smith KD, Hood LE, Aderem A (2005) The evolution of vertebrate Toll-like receptors. Proc Natl Acad Sci USA 102:9577-9582

Sauter KS, Brcic M, Franchini M, Jungi TW (2007) Stable transduction of bovine TLR4 and bovine MD-2 into LPSnonresponsive cells and soluble CD14 promote the ability to respond to LPS. Vet Immunol Immunopathol 118:92-104

Schneberger D, Caldwell S, Suri SS, Singh B (2009) Expression of toll-like receptor 9 in horse lungs. Anat Rec 292:1068-1077 
Schwandner R, Dziarski R, Wesche H, Rothe M, Kirschning CJ (1999) Peptidoglycan- and lipoteichoic acid-induced cell activation is mediated by toll-like receptor 2. J Biol Chem 274:17406-17409

Schwarz H, Schneider K, Ohnemus A, Lawric M, Kothlow S, Bauer S, Kaspers B, Staeheli P (2007) Chicken toll-like receptor 3 recognizes its cognate ligand when ectopically expressed in human cells. J Interferon Cytokine Res 27:97-101

Seabury CM, Cargill EJ, Womack JE (2007) Sequence variability and protein domain architectures for bovine Toll-like receptors 1, 5, and 10. Genomics 90:502-515

Seabury CM, Seabury PM, Decker JE, Schnabel RD, Taylor JF, Womack JE (2010) Diversity and evolution of 11 innate immune genes in Bos taurus taurus and Bos taurus indicus cattle. Proc Natl Acad Sci USA 107:151-156

Sharma A, Maheshwari RK (2009) Oligonucleotide array analysis of Toll-like receptors and associated signalling genes in Venezuelan equine encephalitis virus-infected mouse brain. J Gen Virol 90:1836-1847

Shimosato T, Tohno M, Kitazawa H, Katoh S, Watanabe K, Kawai Y, Aso H, Yamaguchi T, Saito T (2005) Toll-like receptor 9 is expressed on follicle-associated epithelia containing $\mathrm{M}$ cells in swine Peyer's patches. Immunol Lett 98:83-89

Shinkai H, Muneta Y, Suzuki K, Eguchi-Ogawa T, Awata T, Uenishi H (2006a) Porcine Toll-like receptor 1, 6, and 10 genes: complete sequencing of genomic region and expression analysis. Mol Immunol 43:1474-1480

Shinkai H, Tanaka M, Morozumi T, Eguchi-Ogawa T, Okumura N, Muneta Y, Awata T, Uenishi H (2006b) Biased distribution of single nucleotide polymorphisms (SNPs) in porcine Toll-like receptor 1 (TLR1), TLR2, TLR4, TLR5, and TLR6 genes. Immunogenetics 58:324-330

Singh Suri S, Janardhan KS, Parbhakar O, Caldwell S, Appleyard G, Singh B (2006) Expression of toll-like receptor 4 and 2 in horse lungs. Vet Res 37:541-551

Sun J, Fegan PE, Desai AS, Madara JL, Hobert ME (2007) Flagellininduced tolerance of the Toll-like receptor 5 signaling pathway in polarized intestinal epithelial cells. Am J Gastrointest Liver Physiol 293:G767-G778

Swerdlow MP, Kennedy DR, Kennedy JS, Washabau RJ, Henthorn PS, Moore PF, Carding SR, Felsburg PJ (2006) Expression and function of TLR2, TLR4, and Nod2 in primary canine colonic epithelial cells. Vet Immunol Immunopathol 114:313-319

Takeda K, Kaisho T, Akira S (2003) Toll-like receptors. Annu Rev Immunol 21:335-376

Takeuchi O, Hoshino K, Kawai T, Sanjo H, Takada H, Ogawa T, Takeda K, Akira S (1999) Differential roles of TLR2 and TLR4 in recognition of gram-negative and gram-positive bacterial cell wall components. Immunity 11:443-451

Tamai R, Asai Y, Hashimoto M, Fukase K, Kusumoto S, Ishida H, Kiso M, Ogawa T (2003) Cell activation by monosaccharide lipid A analogues utilizing Toll-like receptor 4. Immunology 110:66-72

Temperley ND, Berlin S, Paton IR, Griffin DK, Burt DW (2008) Evolution of the chicken Toll-like receptor gene family: a story of gene gain and gene loss. BMC Genomics 9:62-73

Tirumurugaan KG, Dhanasekaran S, Raj GD, Raja A, Kumanan K, Ramaswamy V (2010) Differential expression of toll-like receptor mRNA in selected tissues of goat (Capra hircus). Vet Immunol Immunopathol 15:296-301

Tohno M, Kitazawa H, Shimozato T, Matsumoto M, Katoh S, Kawai Y, Saito T (2005a) A swine toll-like receptor 2-expressing transfectant as a potential primary screening system for immunobiotic microorganisms. FEMS Immunol Med Microbiol 44:283-288

Tohno M, Shimosato T, Kitazawa H, Katoh S, Iliev ID, Kimura T, Kawai Y, Watanabe K, Aso H, Yamaguchi T, Saito T (2005b)
Toll-like receptor 2 is expressed on the intestinal $M$ cells in swine. Immunol Lett 98:83-89

Tohno M, Shimosato T, Moue M, Aso H, Watanabe K, Kawai Y, Yamaguchi T, Saito T, Kitazawa H (2006) Toll-like receptor 2 and 9 are expressed and functional in gut-associated lymphoid tissues of presuckling newborn swine. Vet Res 37:791-812

Tohno M, Shimazu T, Aso H, Kawai Y, Saito T, Kitazawa H (2007) Molecular cloning and functional characterization of porcine MyD88 essential for TLR signaling. Cell Mol Immunol 4:369376

Travassos LH, Girardin SE, Philpott DJ, Blanot D, Nahori MA, Werts C, Boneca IG (2004) Toll-like receptor 2-dependent bacterial sensing does not occur via peptidoglycan recognition. EMBO Rep 5:1-7

Turin L, Riva F (2008) Toll-like receptor family in domestic animal species. Crit Rev Immunol 28:513-538

Vaharan BM, Raj GD, Rawar RM, Gopinath VP, Raja A, Thanawelu A (2008) Expression profile of toll like receptors in a range of water buffalo tissues (Bubalus bubalis). Vet Immunol Immunopathol 126:149-155

Van der Pool T (2010) Toll-like Receptor 4 in health and disease. Cell Tiss Res (special issue)

Van der Sar AM, Stockhammer OW, van der Laan C, Spaink HP, Bitter W, Meijer AH (2006) MyD88 innate immune function in a zebrafish embryo infection model. Infect Immun 74:2436-2441

Vychodilova-Krenkova L, Matiasociv J, Horin P (2005) Single nucleotide polymorphisms in four functionally related immune response genes in the horse: CD14, TLR4, Cepsilon, and Fcepsilon R1 alpha. Int J Immunogenet 32:277-283

Wassef A, Janardhan K, Pearce JW, Singh B (2004) Toll-like receptor 4 in normal and inflamed lungs and other organs of pig, dog and cattle. Histol Histopathol 19:1201-1208

Werling D, Jungi TW (2003) Toll-like receptors linking innate and adaptive immmune response. Vet Immunol Immunopathol 91:1-12

Werling D, Coffey TJ (2007) Pattern recognition receptors in companion and farm animals - The key to unlocking the door to animal disease? Vet J 174:240-251

Werling D, Piercy J, Coffey TJ (2006) Expression of TOLL-like receptors (TLR) by bovine antigen-presenting cells - potential role in pathogen discrimination? Vet Immunol Immunopathol 112:2-11

Werling D, Jann OC, Offord V, Glass EJ, Coffey TJ (2009) Variation matters: TLR structure and species-specific pathogen recognition. Trends Immunol 30:124-130

Yang W, Zerbe H, Petzl W, Brunner RM, Günther J, Draing C, von Aulock S, Schuberth HJ, Seyfert HM (2008) Bovine TLR2 and TLR4 properly transduce signals from Staphylococcus aureus and $E$. coli, but $S$. aureus fails to both activate NF-kappaB in mammary epithelial cells and to quickly induce TNFalpha and interleukin-8 (CXCL8) expression in the udder. Mol Immunol 45:1385-1397

Zähringer U, Lindner B, Inamura S, Heine H, Alexander C (2008) TLR2 - promiscuous or specific? A critical re-evaluation of a receptor expressing apparent broad specificity. Immunobiology 213:205-224

Zhang Y, Shoda LK, Brayton KA, Estes DM, Palmer GH, Brown WC (2001) Induction of interleukin- 6 and interleukin-12 in bovine B lymphocytes, monocytes, and macrophages by a $\mathrm{CpG}$ oligodeoxynucleotide (ODN 2059) containing the GTCGTT motif. J Interferon Cytokine Res 21:871-881

Zhou ML, Shi JX, Hang CH, Zhang FF, Gao J, Yin HX (2007) Expression of Toll-like receptor 4 in the brain in a rabbit experimental subarachnoid haemorrhage model. Inflamm Res 56:93-97 